\title{
SKARGA NADZWYCZAJNA - DOPELNIAJĄCY CZY KONKURENCYJNY WOBEC SKARGI KONSTYTUCYJNEJ INSTRUMENT OCHRONY KONSTYTUCYJNYCH WOLNOŚCI I PRAW JEDNOSTKI
}

\author{
EXTRAORDINARY COMPLAINT - A SUPPLEMENTING OR COMPETING INSTRUMENT \\ OF PROTECTING CONSTITUTIONAL FREEDOMS AND RIGHTS OF AN INDIVIDUAL \\ VIS-À-VIS THE CONSTITUTIONAL COMPLAINT
}

On 3 April 2018, a new law on the Supreme Court went into force, introducing a new institution - an extraordinary complaint. According to the intention of its authors, the construction of extraordinary complaint emphasises the need for the courts to respect constitutional principles and constitutionally protected freedoms, as well as human and civil rights. Not referring here to the aims, needs and anticipated effects of the functioning of this instrument in the legal system of Poland - taking into account the shape of the extraordinary complaint adopted by the legislator - it should be regarded as complementing the constitutional complaint (at least in the field of civil and criminal law) and an instrument to increase the effectiveness of protection of constitutional freedoms and individual rights. It is necessary to wait for the assessment of the introduction of this measure into the Polish legal system. At the same time, one cannot lose sight of fears and doubts raised against this instrument in the course of legislative procedure. However, if the extraordinary complaint supplements the constitutional complaint in those areas where the latter - due to its legal or practical limitations - is not effective, introduction of the same or similar institution into administrative proceedings shall be considered.

Słowa kluczowe: skarga konstytucyjna, skarga nadzwyczajna, prawa i wolności jednostki, zasady konstytucyjne, Sąd Najwyższy, Trybunał Konstytucyjny, stosowanie prawa, kontrola zgodności prawa z konstytucją

Key words: constitutional complaint, extraordinary complaint, individual rights and freedoms, constitutional principles, Supreme Court, Constitutional Tribunal, application of law, review of the constitutionality of law

* Dr Anna Michalak, Uniwersytet Łódzki, Wydział Prawa i Administracji, adiunkt w Katedrze Prawa Konstytucyjnego, amichalak@wpia.uni.lodz.pl, https//orcid.org/0000-0001-7430-5817

\section{WSTĘP}

Z dniem 3 kwietnia 2018 r. weszła w życie ustawa o Sądzie Najwyższym', którą wprowadzano nową instytucję — skargę nadzwyczajną. Zgodnie z intencją projektodawcy konstrukcja tej skargi uwypukla konieczność respektowania przez sądy przy orzekaniu zasad konstytucyjnych oraz chronionych konstytucyjnie wolności oraz praw człowieka i obywatela. Instytucja skargi nadzwyczajnej nie koliduje przy tym — jak wskazano w uzasadnieniu projektu ustawy — z instytucją skargi konstytucyjnej (art. 79 ust. 1 konstytucji), ponieważ skarga konstytucyjna nie służy

${ }^{1}$ Ustawa z dnia 8 grudnia 2017 r. (Dz.U. z 2018 r. poz. 5, ze zm.). 
ochronie konkretnych interesów jednostek, ale „odrywa się od generującego skargę konstytucyjną naruszenia wolności lub prawa, a rozstrzygnięcie obejmuje jedynie hierarchiczną kontrolę norm"². Orzecznictwo Trybunału Konstytucyjnego wskazuje, że niedopuszczalna jest skarga konstytucyjna, w której zarzuty dotyczą wadliwego ustalenia stanu faktycznego albo wyłącznie indywidualnego rozstrzygnięcia. Skarga konstytucyjna nie jest bowiem środkiem umożliwiającym bezpośrednią ochronę praw lub wolności konstytucyjnych, które naruszono w rezultacie wydania indywidualnego aktu stosowania prawa ${ }^{3}$, lecz jest jednym ze środków umożliwiających kontrolę hierarchicznej zgodności aktów normatywnych, który — w razie wydania wyroku stwierdzającego niezgodność aktu normatywnego będącego podstawą rozstrzygnięcia z aktem hierarchicznie wyższym - jedynie umożliwia żądanie wznowienia postępowania w sprawie. Z tego względu - w opinii projektodawcy ustawy o SN — niezbędne jest uzupełnienie systemu prawnego o instytucję chroniącą konstytucyjne wolności i prawa obywateli, w przypadku ich naruszenia wyrokami sądów, w sytuacjach nadzwyczajnych, gdy istniejące środki prawne są niewystarczające do ich ochrony ${ }^{4}$.

W trakcie prac legislacyjnych nad ustawą o SN zgłaszano istotne zastrzeżenia i wątpliwości co do potrzeby wprowadzenia proponowanego kształtu i przewidywanych skutków funkcjonowania skargi nadzwyczajnej w systemie prawa. Wśród najpoważniejszych zastrzeżeń wskazywano: możliwość sparaliżowania wymiaru sprawiedliwości oraz instytucji publicznych, za pośrednictwem których skarga ta ma być wnoszona do $\mathrm{SN}^{5}$; destabilizację porządku prawnego i obrotu prawnego ${ }^{6}$; naruszenie stabilności orzecznictwa i gwarantowanych konstytucyjnie zasad powagi rzeczy osądzonej oraz zaufania obywateli do państwa i stanowionego prawa ${ }^{7}$. Trudno nie zgodzić się z tymi zastrzeżeniami ekspertów, a sygnalizowane przez nich zagrożenia uznać za wyolbrzymione czy wręcz nierealne. Należy stwierdzić, że skarga nadzwyczajna w formie określonej w ustawie o SN — zwłaszcza wobec zastosowanej techniki legislacyjnej, polegającej na użyciu pojęć niedookreślonych i ocennych, do zdefiniowania przesłanek jej wniesienia, a także w związku z przyjętym założeniem, że sprawy te będą rozstrzygane z udziałem ławników — będzie instrumentem zakłócającym funkcjonowanie wymiaru

2 Z. Czeszejko-Sochacki, Formy naruszenia konstytucyjnych wolności lub praw, [w:] Skarga konstytucyjna, red. J. Trzciński, Warszawa 2003, s. 82.

3 Vide np. postanowienie TK z 16 czerwca 2014 r., sygn. akt Ts 214/13, OTK ZU 2015/5B/435.

4 Vide uzasadnienie prezydenckiego projektu ustawy o SN, <http://www.prezydent.pl/prawo>, dostęp 10 II 2018.

5 B. Banaszak, Opinia o zgodności z Konstytucją RP przedłożonego przez Prezydenta projektu ustawy o Sądzie Najwyższym, druk nr 2003, VIII kadencja Sejmu. Opinie Biura Analiz Sejmowych, s. 6, $<$ http://www.sejm.gov.pl>, dostęp 6 IV 2018.

${ }^{6}$ M. Matczak, Opinia prawna w sprawie konstytucyjności prezydenckiego projektu ustawy o Sądzie Najwyższym, druk nr 2003, VIII kadencja Sejmu. Opinie Biura Analiz Sejmowych, s. 7 i n., <http://www. sejm.gov.pl>, dostęp 26 VIII 2018; oraz M. Dobrowolski, Opinia o zgodności z Konstytucją RP przedłożonego przez Prezydenta projektu ustawy o Sądzie Najwyższym, druk nr 2003..., s. 8.

7 S. Patyra, Opinia prawna na temat zgodności z Konstytucja Rzeczypospolitej Polskiej przedstawionego przez Prezydenta Rzeczpospolitej Polskiej projektu ustawy o Sądzie Najwyższym, druk nr $2003 \ldots$, s. 18 i n. 
sprawiedliwości i zasad demokratycznego państwa prawnego z zasadą pewności prawa na czele. Niemniej skoro ustawodawca zdecydował się wprowadzić tę instytucję do polskiego porządku prawnego, nie należy liczyć, że będzie to instytucja martwa i niewykorzystywana w praktyce. Wręcz przeciwnie, należy raczej spodziewać się — przynajmniej w początkowym okresie jej funkcjonowania - dużego zainteresowania tym środkiem wzruszania prawomocnych orzeczeń ${ }^{8}$.

$\mathrm{Na}$ etapie opiniowania przepisów dotyczących skargi nadzwyczajnej zwracano uwagę na to, że skoro polski model skargi konstytucyjnej wyraźnie odbiega od standardów występujących w innych rozwiniętych państwach demokratycznych, w których ta skarga istnieje, to pożądane jest dostarczenie jednostce środka zaskarżenia o charakterze nadzwyczajnym; środka, który nie będzie konkurencją dla skargi konstytucyjnej, ale będzie ją uzupełniał, umożliwiając ochronę konstytucyjnych praw i wolności we wszystkich przypadkach, w których skorzystanie ze skargi konstytucyjnej nie jest możliwe9. W mojej ocenie — wobec braku efektywności skargi konstytucyjnej — uznanie, że skarga nadzwyczajna będzie jej dopełnieniem (przynajmniej w odniesieniu do stosowania przepisów z zakresu prawa cywilnego i karnego) i że może ona wpłynąć na zwiększenie efektywności ochrony konstytucyjnych wolności i praw jednostki stanowi jedyną przesłankę pozytywnej oceny nowej instytucji i uzasadnia jej utrzymanie w polskim systemie prawnym. Niemniej decyzja ta nie może abstrahować od praktyki funkcjonowania skargi nadzwyczajnej, a na dokonanie ewaluacji w tym zakresie trzeba poczekać.

Celem autora niniejszej publikacji jest wskazanie skali braku efektywności skargi konstytucyjnej i jej przyczyn oraz wykazanie, że skarga nadzwyczajna może stanowić - choć w ograniczonym zakresie — istotne wzmocnienie systemu ochrony konstytucyjnych wolności i praw jednostki.

\section{MODEL SKARGI KONSTYTUCYJNEJ W KONTEKŚCIE KONSTYTUCJI RP I ORZECZNICTWA TRYBUNALU KONSTYTUCYJNEGO}

Uregulowana w art. 79 konstytucji skarga konstytucyjna jest środkiem ochrony konstytucyjnych praw i wolności oraz jednym ze sposobów zainicjowania postępowania przed TK, którego celem jest zbadanie konstytucyjności przepisów prawa stanowionego. W art. 79 ust. 1 konstytucji jednoznacznie przesądzono o tym, że polska skarga konstytucyjna ma wąski charakter przedmiotowy (skargę można wnieść na przepis ustawy lub innego aktu normatywnego, na podstawie którego orzekł sąd lub organ administracji) i szeroki zakres podmiotowy (zdolność skargową posiada „każdy”).

${ }^{8}$ Do końca lipca 2018 r. do biura Rzecznika Praw Obywatelskich [dalej: RPO] spłynęło 1013 wniosków o skargę nadzwyczajną. Jak ustaliła „Rzeczpospolita”, liczba takich wniosków złożonych m.in. do Prokuratury Krajowej, Prokuratorii Generalnej czy Rzecznika Praw Dziecka może przekraczać 600 (vide Skarga nadzwyczajna: Polacy złożyli już ponad 600 wniosków, „Rzeczpospolita”, 3 V 2018. Natomiast 10 sierpnia 2018 r. RPO wniósł do SN pierwszą skargę nadzwyczajną (vide Pierwsza skarga nadzwyczajna RPO do SN: w imię Konstytucji niesie pomoc spadkobiercom rolniczki, <http://www.rpo.gov.pl>, dostęp 10 VIII 2018.

${ }_{9}^{9}$ B. Banaszak, Opinia o zgodności z Konstytucją RP..., s. 6. 
Polski ustrojodawca przyjął zatem taki model skargi na akt normatywny, który wyklucza możliwość kwestionowania w ramach tej procedury orzeczeń i decyzji wydawanych $\mathrm{w}$ indywidualnych sprawach ${ }^{10}$.

Następstwem uwzględnienia skargi konstytucyjnej jest usunięcie z systemu prawnego niekonstytucyjnego przepisu, który był podstawą prawną orzeczenia wydanego w sprawie skarżącego, oraz umożliwienie skarżącemu wzruszenia tego orzeczenia i uzyskania rozstrzygnięcia w nowym (zgodnym z konstytucją) stanie prawnym (art. 190 ust. 4 konstytucji). Dopiero możliwość skorzystania z prawa wznowienia postępowania, uchylenia decyzji lub innego rozstrzygnięcia czyni skargę konstytucyjną faktycznym środkiem ochrony konstytucyjnych praw i wolności ${ }^{11}$. Przyjęcie obecnego modelu skargi konstytucyjnej było zdeterminowane wieloma względami, przede wszystkim pragmatycznymi wynikającymi $\mathrm{z}$ obawy przed masowym korzystaniem przez obywateli z nowego środka ochrony praw i wolności jednostki, dotychczasową koncepcją TK jako ,organu rozstrzygającego o prawach w sensie przedmiotowym, a nie podmiotowym", a przede wszystkim wizją konfliktów z organami stosującymi prawo, zwłaszcza z sądami. Znaczące było także stanowisko sądów w tej kwestii, zwłaszcza Sądu Najwyższego, a także Krajowej Rady Sądownictwa. Nie budzi zatem wątpliwości, że polski ustrojodawca wyraźnie przyznał prymat przedmiotowej funkcji skargi konstytucyjnej, związanej z podstawowym celem sądu konstytucyjnego, jakim jest ochrona przestrzegania konstytucji. Natomiast na drugim planie pozostała kwestia ochrony jednostki (skarżącego), która stanowi jedynie refleks funkcji podstawowej (brak bezpośredniego charakteru ochrony udzielanej przez TK prawom lub wolnościom skarżącego) ${ }^{12}$. Należy przy tym zgodzić się z tezą, że brak możliwości kierowania skarg bezpośrednio przeciwko aktom indywidualnym, zwłaszcza orzeczeniom sądowym, a także bezpośredniego orzekania przez Trybunał w przedmiocie uchylania aktów indywidualnych, stanowią dwie główne cechy polskiego modelu skargi konstytucyjnej ${ }^{13}$.

Zdaniem wielu przedstawicieli doktryny regulacja konstytucyjna przesądziła o tym, że przyjęty środek jest $\mathrm{w}$ istocie wnioskiem indywidualnym, a nie środkiem ochrony wolności i praw w ścisłym tego słowa znaczeniu ${ }^{14}$. W orzecznictwie TK wyraźnie się podkreśla, że skarga konstytucyjna dotyczy niezgodności z konstytucją przepisów

${ }^{10}$ B. Banaszak, Jakie zmiany w Konstytucji RP sa potrzebne, [w:] Aktualne problemy reform konstytucyjnych, red. S. Bożyk, Białystok 2013, s. 35 i n.

${ }^{11}$ M. Florczak-Wątor, Skarga konstytucyjna jako środek ochrony konwencyjnych praw $i$ wolności jednostki, [w:] Prawo międzynarodowe i europejskie a sądownictwo konstytucyjne, red. P. Tuleja, Kraków 2015, s. 68.

${ }^{12}$ S. Jarosz-Żukowska, Prawo do skargi konstytucyjnej - stan obecny i postulaty de lege ferenda, [w:] Realizacja i ochrona konstytucyjnych wolności i praw jednostki w polskim porządku prawnym, red. M. Jabłoński, Wrocław 2014, s. 827 i n.

${ }^{13}$ M. Safjan, Pozycja Trybunatu Konstytucyjnego w Konstytucji Rzeczypospolitej Polskiej z 1997 roku. Nowe instrumenty i metody działania, [w:] Pięć lat Konstytucji Rzeczypospolitej Polskiej, red. H. Jerzmański, Warszawa 2002, s. 37.

${ }^{14}$ Confer np. P. Tuleja, W. Wróbel, Skarga konstytucyjna, czyli dodatkowa gwarancja praw cztowieka. W Polsce i gdzie indziej, „Rzeczpospolita”, 14 XII 1997. 
ustawy lub innych aktów normatywnych, a nie indywidualnych rozstrzygnięć w konkretnej sprawie ${ }^{15}$. Z zakresu stosowania skargi wyłączone są zatem akty stosowania prawa, a także bezczynność organów władzy publicznej, w tym także zaniechanie ustawodawcy ${ }^{16}$. W moim przekonaniu o wiele bardziej znaczący wpływ na brak efektywności skargi konstytucyjnej, jako środka ochrony wolności i praw konstytucyjnych, miało jednak — wykształcone w kontekście ustawy o TK z 1997 r. ${ }^{17}$ — orzecznictwo $^{18}$, które ze względu na powtórzenie takich samych rozwiązań legislacyjnych w kolejnych ustawach o $\mathrm{TK}^{19}$ także obecnie znajduje odpowiednie zastosowanie przy interpretowaniu przesłanek funkcjonowania tej instytucji. W szczególności negatywnie należy ocenić te orzeczenia, w których zastosowana wykładnia przesłanek warunkując dopuszczalność skargi konstytucyjnej ${ }^{20}$ wpłynęła na zawężenie nie tylko przedmiotu ${ }^{21}$,

${ }^{15}$ Wyrok TK z 12 listopada 2002 r., sygn. akt SK 40/01, OTK ZU 2002/6A/81.

${ }^{16}$ S. Jarosz-Żukowska, Prawo do skargi konstytucyjnej..., s. 833.

17 Ustawa z dnia 1 sierpnia 1997 r. o Trybunale Konstytucyjnym (Dz.U. nr 102, poz. 643, ze zm.).

${ }^{18}$ Napiał o tym P. Tuleja, wskazując, że kształt skargi konstytucyjnej zdeterminowany jest również orzecznictwem TK. Orzekając w konkretnych sprawach, Trybunał rozstrzygał bowiem wiele istotnych problemów związanych m.in. z interpretacją art. 79, których nie przewidzieli twórcy obowiązującej konstytucji, a które powstały w praktyce funkcjonowania omawianej instytucji; vide P. Tuleja, Skarga konstytucyjna w Polsce — dziesięć lat doświadczeń, „Przegląd Legislacyjny” 2007, nr 3, s. 29-30.

${ }_{19}$ Mam na myśli ustawę o TK z 1997 r., ustawy o Trybunale Konstytucyjnym z dnia: 25 czerwca 2015 r. (Dz.U. poz. 1064), 22 lipca 2016 r. (Dz.U. poz. 1157), ustawę z dnia 13 grudnia 2016 r. — Przepisy wprowadzające ustawę o organizacji i trybie postępowania przed Trybunałem Konstytucyjnym oraz ustawę o statusie sędziów Trybunału Konstytucyjnego (Dz.U. poz. 2074), z dnia 30 listopada 2016 r. o statusie sędziów Trybunału Konstytucyjnego (Dz.U. poz. 2073), z dnia 30 listopada 2016 r. o organizacji i trybie postępowania przed Trybunałem Konstytucyjnym (Dz.U. poz. 2072).

${ }^{20}$ Wśród przesłanek formalnych warunkujących dopuszczalność skargi wątpliwości budzi przede wszystkim przesłanka oczywistej bezzasadności (a poniekąd także brak uprawdopodobnienia naruszenia wolności i praw konstytucyjnych) jako podstawa odmowy nadania skardze konstytucyjnej dalszego biegu. Nie mają one charakteru formalnego - do ich stwierdzenia konieczna jest $\mathrm{w}$ istocie ocena meritum skargi. W orzecznictwie TK można znaleźć stwierdzenie, że przesłanka ta występuje, gdy zarzuty podniesione w skardze wobec danej regulacji „,choćby w najmniejszym stopniu nie uprawdopodabniają negatywnej jej kwalifikacji konstytucyjnej" (postanowienie TK z 23 października 2014 r., sygn. akt Ts 81/13, OTK ZU 2014/5B/417). Oczywistą bezzasadność TK stwierdza także, gdy skarga nie ma ścisłego związku z konkretnym przepisem ustawy albo zakres zaskarżonych przepisów nie ma związku ze stawianymi przez skarżącego zarzutami naruszenia wskazanych wzorców konstytucyjnych (postanowienia TK z dnia: 3 lipca $2014 \mathrm{r}$., sygn. akt Ts 43/14, OTK ZU 2014/4B/357, 11 lipca 2014 r., sygn. akt Ts 22/14, OTK ZU 2014/4B/353, 4 kwietnia 2014 r., sygn. akt Ts 309/13, OTK ZU 2014/2B/176).

${ }^{21}$ Stosując rozszerzającą wykładnię wymogów warunkujących dopuszczalność skarg konstytucyjnych (np. w zakresie obowiązku wyczerpania drogi prawnej, istnienia tzw. przesłanki funkcjonalnej) Trybunał doprowadził do takiego stopnia sformalizowania koniecznych wymogów procesowych skargi konstytucyjnej, że w konsekwencji możliwość realizacji prawa podmiotowego, o którym mowa w art. 79 ust. 1 konstytucji, stała się mało realna. Szczególnie, gdy ukształtowało się już jednolite rozumienie przepisów, które mają stać się przedmiotem skargi konstytucyjnej, lub gdy jednostka już na etapie postępowania w I instancji podnosi zarzut niekonstytucyjności aktu, ale sąd nie podziela tych wątpliwości i nie występuje z pytaniem prawnym do TK. W takiej sytuacji strona postępowania musi skorzystać ze wszystkich środków odwoławczych, godząc się niejako z góry na niekorzystne rozstrzygnięcie, aby móc skorzystać z prawa do złożenia skargi (D. Dudek, Konstytucyjna wolność człowieka a tymczasowe aresztowanie, 
podmiotu ${ }^{22}$ i podstaw ${ }^{23}$ skargi konstytucyjnej, ale również skutków, jakie orzeczenie TK o niezgodności z konstytucją wydane w trybie skargowym wywiera na polski system prawny ${ }^{24}$.

Lublin 2000, s. 223). Jak wynika z ustalonego orzecznictwa TK, rozpoznanie skargi jest dopuszczalne tylko wtedy, gdy jej rozstrzygnięcie ma znaczenie dla sytuacji prawnej skarżącego, w tym sensie, że w razie orzeczenia niezgodności z konstytucją kwestionowanej normy skarżący mógłby uzyskać należną mu ochronę konstytucyjnej wolności lub prawa, której — wobec obowiązywania zaskarżonej normy — mu odmówiono (confer wyrok TK z 22 listopada 2005 r., sygn. akt SK 8/05, OTK ZU 2005/10A/117, postanowienie TK z 13 czerwca 2011 r., sygn. akt SK 26/09, OTK ZU 2011/5A/46). W przypadku zaś, gdy wyrok stwierdzający pominięcie prawodawcze wymaga stosownej aktywności ustawodawcy i nie wywołuje samoistnie skutków, o których mowa w art. 190 ust. 4 konstytucji (prawo do wznowienia postępowania), powyższa przesłanka nie jest spełniona (confer zdanie odrębne sędzi TK M. Pyziak-Szafnickiej do wyroku TK z 13 czerwca 2011 r., sygn. akt SK 41/09, OTK ZU 2011/5A/40).

${ }^{22} \mathrm{~W}$ postanowieniach z 8 listopada 2005 r., sygn. akt Ts 203/04 (OTK ZU 2005/6B/237) i sygn. akt Ts 204/04 (OTK ZU 2005/6B/239), wydanych w składzie trzyosobowym, TK uwzględnił zażalenie spółki KGHM Polska Miedź S.A. na odmowę nadania skardze biegu ze względu na brak zdolności skargowej. Natomiast w postanowieniu z 20 grudnia 2007 r. (sygn. akt SK 67/05, OTK ZU 2007/11A/168), wydanym w składzie pięcioosobowym, Trybunał umorzył postępowanie ze względu na niedopuszczalność wydania wyroku. Confer także postanowienie odmawiające legitymacji spółce KGHM Polska Miedź S.A. z 8 kwietnia 2008 r. (sygn. akt SK 80/06, OTK ZU 2008/3A/51), a także jednoosobowej spółce Skarbu Państwa (Polskie Sieci Elektroenergetyczne S.A.) w postanowieniu z 6 kwietnia 2011 r. (sygn. akt SK 21/07, OTK ZU 2011/3A/28). Podobnie w postanowieniu TK o uwzględnieniu zażalenia z 18 grudnia 2013 r., sygn. akt Ts 13/12, OTK ZU 2014/IIB/833).

${ }^{23}$ Np. brak możliwości uznania art. 2 i art. 32 konstytucji za samodzielne wzorce kontroli w trybie skargi konstytucyjnej (vide postanowienia pełnego składu TK z 23 stycznia 2002 r., sygn. akt Ts 105/00, OTK ZU 2002/1B/60 oraz 16 lutego 2009 r., sygn. akt Ts 202/06, OTK ZU 2009/1B/23). Confer także krytyczne stanowisko w sprawie uznania przez TK art. 31 ust. 3 i art. 32 konstytucji jedynie za ,wzorce o charakterze subsydiarnym, a nie zasadniczym, samodzielnym"; vide M. Masternak-Kubiak, J. Zakolska, Naruszenie zasady proporcjonalności jako podstawa skargi konstytucyjnej, [w:] W stużbie dobru wspólnemu. Ksiegga dedykowana Profesorowi Januszowi Trzcińskiemu, red. M. Masternak-Kubiak, R. Balicki, Warszawa 2012, s. 234-237.

${ }^{24} \mathrm{Na}$ brak efektywności skarg konstytucyjnych jako środka ochrony wolności i praw konstytucyjnych miała wpływ m.in. linia orzecznicza dotycząca skutków „derogacji trybunalskiej” (odjęciu prawa do wznawiania postępowań w ogóle; confer wyrok TK z dnia 24 października 2007 r., sygn. akt SK 7/06, OTK ZU 2007/9A/, poz. 108, dotyczący sprawowania wymiaru sprawiedliwości przez asesorów sądowych) lub w związku z wydaniem orzeczenia o niekonstytucyjności odraczającego utratę mocy obowiązującej zaskarżonych przepisów (szerzej o sporze w doktrynie odnośnie skutków wydania przez TK wyroku z klauzulą odraczającą dla realizacji prawa do wznowienia postępowania vide D. Daniluk, Skutki wyroku Trybunału Konstytucyjnego z klauzulą odraczająca w postępowaniu sądowoadministracyjnym, „Przegląd Prawa Konstytucyjnego" 2011, nr 4, s. 121 i n.). Należy zwrócić uwagę, że Trybunał podjął próbę wypracowania orzecznictwa (vide postanowienie TK z 14 grudnia 2004 r., sygn. akt SK 26/02, OTK ZU 2004/11A/120, wyrok TK z 26 maja 2008 r., sygn. akt SK 25/07, OTK ZU 2008/4A/62) umożliwiającego w pewnych sytuacjach uprzywilejowanie skarżących (tzw. przywilej korzyści lub premia za aktywność (vide T. Liszcz, Głos w dyskusji, [w:] Księga XXV-lecia Trybunału Konstytucyjnego. Ewolucja funkcji i zadań Trybunatu Konstytucyjnego — założenia a ich praktyczna realizacja, red. K. Budziło, Warszawa 2010, s. 263). Praktyka ta spotkała się z krytyką jako pozbawiona podstaw konstytucyjnych (vide P. Radziewicz, „,Przywilej korzyści” jako skutek prawny orzeczenia Trybunatu Konstytucyjnego, „Przegląd Legislacyjny” 2006, nr 4, s. 9 i n. Ostatecznie sam Trybunał uznał brak swej kognicji w tym zakresie: „TK nie posiada kompetencji do określenia, czy i jaki środek prawny przysługuje skarżącej w związku z wydaniem orzeczenia o niekonstytucyjności przepisu, na podstawie którego zostało wydane ostateczne orzeczenie" (vide postanowienie TK z 4 września 2007 r., sygn. akt SK 47/06, OTK ZU 2007/8A/99). 


\section{Tabela 1. Wpływ skarg konstytucyjnych do TK w latach 1997-2016 ${ }^{25}$}

\begin{tabular}{|c|c|c|c|}
\hline Rok & $\begin{array}{c}\text { Liczba } \\
\text { wniesionych } \\
\text { do TK skarg } \\
\text { konstytucyjnych }\end{array}$ & $\begin{array}{l}\text { Liczba skarg konstytucyj- } \\
\text { nych przekazanych } \\
\text { do merytorycznego } \\
\text { rozpoznawania }\end{array}$ & $\begin{array}{l}\text { Skargi konstytucyjne a inne } \\
\text { sprawy, które wpłynęły } \\
\text { do merytorycznego } \\
\text { rozpoznania }(\%)\end{array}$ \\
\hline $1997^{a}$ & 27 & b.d. & b.d. \\
\hline 1998 & 168 & 23 & 13 \\
\hline 1999 & 185 & 31 & 16 \\
\hline 2000 & 200 & 22 & 11 \\
\hline 2001 & 181 & 44 & 24 \\
\hline 2002 & 195 & 44 & 22 \\
\hline 2003 & 210 & 69 & 32 \\
\hline 2004 & 224 & 57 & 25 \\
\hline 2005 & 220 & 70 & 31 \\
\hline 2006 & 294 & 100 & 34 \\
\hline 2007 & 309 & 50 & 16 \\
\hline 2008 & 405 & 66 & 16 \\
\hline 2009 & 321 & 45 & 14 \\
\hline 2010 & 351 & 33 & 9 \\
\hline 2011 & 358 & 30 & 8 \\
\hline 2012 & 320 & 67 & 20 \\
\hline 2013 & 331 & 71 & 21 \\
\hline 2014 & 375 & 44 & 11 \\
\hline 2015 & $408^{b}$ & 48 & 11 \\
\hline 2016 & 267 & 31 & 11 \\
\hline 2017 & 234 & 32 & 13 \\
\hline
\end{tabular}

a Przepisy dotyczące skargi konstytucyjnej weszły w życie z dniem 17 października 1997 r., brak więc danych o przekazaniu ich do merytorycznego rozpoznania za 1997 r. Do 31 grudnia 1997 r. wydano jedynie siedem postanowień o odmowie nadania skardze konstytucyjnej dalszego biegu.

b W tym 103 skargi konstytucyjne wniesione na podstawie przepisów ustawy o TK z 2015 r. (tj. w odniesieniu do których — w przypadku wydania postanowienia o odmowie nadania dalszego biegu na etapie wstępnej kontroli — nie przysługiwało zażalenie).

Źródło: Opracowanie własne na podstawie danych dostępnych na stronie internetowej TK, <www.trybunal. gov.pl>, dostęp 11 II 2018.

${ }^{25}$ Należy podkreślić, że TK nie prowadzi statystyk, które umożliwiałyby stwierdzenie, jaki procent skarg konstytucyjnych przekazanych do merytorycznego rozpoznania skutkuje wydaniem orzeczenia o niekonstytucyjności, które umożliwia skarżącemu wznowienie odpowiedniego postępowania w celu wzruszenia ostatecznego orzeczenia wydanego na podstawie niezgodnego z konstytucją unormowania. 
Tabela 2. Orzeczenia wydawane przez TK na etapie merytorycznego rozpoznania w latach 1997-2016

\begin{tabular}{|c|c|c|c|c|}
\hline Rok & Ogółem & Wyroki & $\mathrm{NK}^{\mathrm{a}}$ & \% ogółu \\
\hline $1997^{b}$ & b.d. & b.d. & b.d. & b.d. \\
\hline 1998 & 55 & 33 & 15 & 27 \\
\hline 1999 & 66 & 52 & 29 & 43 \\
\hline 2000 & 85 & 52 & 29 & 34 \\
\hline 2001 & 93 & 64 & 27 & 29 \\
\hline 2002 & 93 & 61 & 31 & 33 \\
\hline 2003 & 91 & 70 & 27 & 29 \\
\hline 2004 & 116 & 79 & 44 & 37 \\
\hline 2005 & 137 & 92 & 41 & 29 \\
\hline 2006 & 143 & 104 & 47 & 32 \\
\hline 2007 & 146 & 73 & 49 & 33 \\
\hline 2008 & 166 & 93 & 49 & 29 \\
\hline 2009 & 158 & 78 & 38 & 24 \\
\hline 2010 & 117 & 68 & 37 & 31 \\
\hline 2011 & 114 & 59 & 25 & 21 \\
\hline 2012 & 122 & 67 & 35 & 28 \\
\hline 2013 & 127 & 71 & 39 & 30 \\
\hline 2014 & $119^{c}$ & 71 & 38 & 31 \\
\hline 2015 & 173 & 63 & 35 & 20 \\
\hline 2016 & 99 & 39 & 17 & 17 \\
\hline $2017^{d}$ & $89^{\mathrm{e}}$ & 36 & b.d. & b.d. \\
\hline
\end{tabular}

a Wyroki o niezgodności z konstytucją co najmniej jednego z zakwestionowanych przepisów. W latach 1998-2014 TK wydał 1187 wyroków, w tym w 600 orzekł o niezgodności z konstytucją co najmniej jednego przepisu, co stanowi 51\% wszystkich wydawanych wyroków. W latach 2015-2016 wyroki takie stanowiły $44 \%$ wyroków wydawanych przez TK.

b Wraz z wejściem w życie w dniu 17 października 1997 r. nowej ustawy zasadniczej zmieniły się zasady funkcjonowania TK, m.in. wprowadzono instytucję skargi konstytucyjnej. Do 31 grudnia 1997 r. na podstawie nowych przepisów TK nie wydał ani jednego wyroku z sprawie ze skargi konstytucyjnej.

c Wydając 119 orzeczeń, TK rozpoznał 157 spraw (część z nich rozpoznana została łącznie).

d Należy podkreślić, że na dzień 31 grudnia 2017 r. nierozpoznanych pozostało nadal 59 skarg przekazanych do merytorycznego rozpoznania w latach: 2013 r. — jedna skarga, 2014 r. — pięć skarg, 2015 r. — 10, 2016 r. $-16,2017$ r. -27.

e Rozpoznano 100 spraw, z których niektóre zostały przekazane do łącznego rozpoznania.

Źródło: Opracowanie własne na podstawie danych dostępnych na stronie internetowej TK, <www. trybunal.gov.pl>, dostęp 11 II 2018. 
Brak efektywności skargi konstytucyjnej w kontekście kolejnych ustaw o TK (które przy modelu skargi konstytucyjnej wykreowanym w konstytucji nie mogły znacząco zmienić praktyki jej funkcjonowania) jest szeroko komentowany przez przedstawicieli doktryny ${ }^{26}$, a przyczyny takiej oceny ilustruje m.in. tabela 1 . Jeśli dodatkowo zwrócimy uwagę na fakt, że średni czas rozpatrywania skargi konstytucyjnej wynosi pięć lat ${ }^{27}$, a uzyskanie orzeczenia o niezgodności przepisu z konstytucją dopiero otwiera skarżącemu drogę do wzruszenia ostatecznego orzeczenia w trybie wznowienia odpowiedniego postępowania (przy czym wniesienie skargi konstytucyjnej — co do zasady — nie wstrzymuje przecież wykonania tego orzeczenia), to możemy uznać, że tylko najwytrwalsi obywatele i kwerulanci sądowi zdecydują się skorzystać z tego instrumentu ochrony.

\section{SKARGA NADZWYCZAJNA JAKO INSTRUMENT OCHRONY KONSTYTUCYJNYCH WARTOŚCI}

Zgodnie z art. $89 \S 1$ pkt 1 ustawy o SN, jeżeli jest to konieczne w celu zapewnienia zgodności z zasadą demokratycznego państwa prawnego urzeczywistniającego zasady sprawiedliwości społecznej, od prawomocnego orzeczenia sądu powszechnego lub sądu wojskowego kończącego postępowanie w sprawie może zostać wniesiona skarga nadzwyczajna, o ile:

a) orzeczenie narusza zasady lub wolności i prawa człowieka i obywatela określone w konstytucji;

b) orzeczenie w sposób rażący narusza prawo przez błędną jego wykładnię albo niewłaściwe zastosowanie lub

c) zachodzi oczywista sprzeczność między istotnymi ustaleniami sądu a treścią zebranego w sprawie materiału dowodowego, a orzeczenie nie może zostać uchylone lub zmienione w trybie innych nadzwyczajnych środków zaskarżenia.

26 Vide np. A. Łabno, Skarga konstytucyjna jako środek ochrony praw człowieka. Przyczynek do dyskusji, „Przegląd Prawa Konstytucyjnego” 2012, nr 4, s. 39-59; S. Jarosz-Żukowska, Prawo do skargi konstytucyjnej...; M. Wiącek, Formalne przesłanki skargi konstytucyjnej (w świetle orzecznictwa TK), „Państwo i Prawo” 2011, z. 9, s. 20-34; S. Jarosz-Żukowska, W sprawie pożądanych zmian polskiego modelu skargi konstytucyjnej, [w:] Konieczne i pożądane zmiany Konstytucji RP z 2 kwietnia 1997 r., red. B. Banaszak, M. Jabłoński, Wrocław 2010, s. 251-282.

${ }^{27}$ Należy podkreślić, że w podawanym przez TK w opracowaniach statystycznych średnim czasie rozpoznawania sprawy zakończonej wyrokiem jako wynoszący w 2015 r. 17 miesięcy (Informacja o istotnych problemach wynikających z działalności i orzecznictwa Trybunału Konstytucyjnego w 2016 r., s. 85, <http:// trybunal.gov.pl>, dostęp 29 VI 2018) nie uwzględnia się czasu między wniesieniem skargi konstytucyjnej a przekazaniem jej do merytorycznego rozpoznania. Aby ustalić faktyczny czas, jaki upływa między wniesieniem skargi a uzyskaniem orzeczenia trybunalskiego, warto przytoczyć parę przykładów: w sprawie o sygn. akt SK 18/17 (termin do wytoczenia powództwa o zaprzeczenie ojcostwa) skarga wpłynęła 14 grudnia 2015 r., a wyrok zapadł 16 maja 2018 r.; w sprawie o sygn. akt SK 8/14 (ochrona informacji niejawnych) skarga wpłynęła 7 października 2013 r., a wyrok zapadł 23 maja 2018 r.; w sprawie o sygn. akt SK 13/14 (prawo do sądu; pozbawienie skarżącego prawa do udziału w posiedzeniu sądu w przedmiocie wykonywania środka zabezpieczającego - umieszczenie w zamkniętym zakładzie psychiatrycznym) skarga została wniesiona 18 grudnia 2012 r., a wyrok zapadł 22 marca 2017 r. Do wyjątków należą skargi rozpatrywane w terminie krótszym. 
Biorąc pod uwagę literalne brzmienie tego przepisu, należy przyjąć, ze skarga nadzwyczajna jako środek ochrony konstytucyjnych wolności i praw jednostki jest dopuszczalna, gdy kumulatywnie zostają spełnione następujące przesłanki:

a) istnieje prawomocne orzeczenie kończące postępowanie w sprawie,

b) orzeczenie to zostało wydane przez sąd powszechny lub wojskowy ${ }^{28}$,

c) orzeczenie to nie może być uchylone lub zmienione w trybie innych nadzwyczajnych środków zaskarżenia,

d) orzeczenie to narusza konstytucyjne zasady lub wolności i prawa jednostki określone w konstytucji, orzeczenie w sposób rażący narusza prawo przez błędną jego wykładnię lub niewłaściwe zastosowanie, lub zachodzi oczywista sprzeczność istotnych ustaleń sądu $\mathrm{z}$ treścią zebranego w sprawie materiału dowodowego,

e) wzruszenie prawomocnego orzeczenia jest konieczne do zapewnienia zgodności z zasadą demokratycznego państwa prawnego urzeczywistniającego zasady sprawiedliwości społecznej.

Uzasadniając potencjalną rolę skargi nadzwyczajnej w ochronie konstytucyjnie poręczonych wolności i praw jednostki, należy zatem - w kontekście ustawy o SN — rozważyć:

a) co oznacza termin prawomocne orzeczenie w kontekście potencjalnego wymogu wyczerpania drogi prawnej i ostateczności tego orzeczenia,

b) czy skorzystać z prawa do wniesienia skargi nadzwyczajnej można wyłącznie w imieniu bądź na wniosek strony postępowania ${ }^{29}$, w którym to orzeczenie zapadło,

c) jak rozumieć wymóg, zgodnie z którym podstawą skargi nadzwyczajnej nie mogą być zarzuty, które były przedmiotem rozpoznawania przez SN przy rozpatrywaniu skargi kasacyjnej lub kasacji (art. 90 § 2 ustawy o SN),

d) naruszenie jakich konstytucyjnych zasad, czyich wolności i praw może stanowić podstawę skargi nadzwyczajnej,

e) co oznacza wymóg zapewnienia zgodności z zasadą demokratycznego państwa prawnego urzeczywistniającego zasady sprawiedliwości społecznej.

Zgodnie z regulacją art. $363 \S 1$ k.p.c. orzeczenie sądu staje się prawomocne, jeżeli nie przysługuje do niego środek odwoławczy lub inny środek zaskarżenia. Z uzyskaniem przez orzeczenie prawomocności formalnej mamy do czynienia, w sytuacji gdy: od orzeczenia nie przewidziano w prawie żadnego środka zaskarżenia, strona zrzekła się prawa do wniesienia środka zaskarżenia, upłynął termin do wniesienia środka zaskarżenia, wniesiony w terminie środek zaskarżenia nie został uwzględniony.

${ }^{28}$ Skarga nadzwyczajna nie przysługuje zatem od orzeczeń wydawanych przez sądy administracyjne, a należy podkreślić, że znaczący procent skarg konstytucyjnych jest wnoszonych w odniesieniu do przepisów prawa administracyjnego oraz podatkowego. W wielu przypadkach nie mogą one być rozpoznane, ponieważ w istocie stanowią skargi na stosowanie prawa (tzn. wiążą naruszenie konstytucyjnych wolności i praw skarżącego z niewłaściwym zastosowaniem prawa w ich sprawie, brakiem ich jednolitej wykładni).

${ }^{29}$ Wątpliwości w tym zakresie mogą dotyczyć zwłaszcza pokrzywdzonego niedziałającego jako oskarżyciel posiłkowy w postępowaniu przed sądem; confer art. 53 ustawy z dnia 6 czerwca 1997 r. Kodeks postępowania karnego (Dz.U. z 2017 r. poz. 1904, ze zm.; dalej: k.p.k.), a także organizacji pozarządowych, które nie uczestniczyły w sprawie, art. 63 ustawa z dnia 17 listopada 1964 r. — Kodeks postępowania cywilnego (Dz.U. z 2016 r. poz. 1822, ze zm.; dalej: k.p.c.). 
Natomiast w kodeksie postępowania karnego nie zawarto definicji pojęcia ,prawomocność". Orzeczenie sądu staje się prawomocne, gdy od niego nie przysługują już zwykłe środki zaskarżenia. Wyrok może być prawomocny nie tylko w całości, ale także w części (jeśli zostanie zaskarżony jedynie wobec jednego oskarżonego lub w zakresie jednego czynu oskarżonego). W takim przypadku wyrok staje się prawomocny w niezaskarżonej części. Orzeczenie sądu staje się zatem prawomocne, w sytuacji gdy: bezskutecznie upłynął termin do wniesienia zwyczajnego środka odwoławczego (termin ten musi upłynąć bezskutecznie dla wszystkich osób uprawnionych do wniesienia środka odwoławczego); prezes sądu I instancji odmówił przyjęcia wniesionego środka odwoławczego (art. 429 § 1 k.p.k.); sąd odwoławczy pozostawił wniesiony środek odwoławczy bez rozpoznania (art. $430 \S 1$ k.p.k.); sąd pozostawił bez rozpoznania cofnięty środek odwoławczy (art. $432 \S 1$ k.p.k.); nie wniesiono wniosku o sporządzenie uzasadnienia wyroku (art. $422 \S 1$ k.p.k.); został wyczerpany tok instancji wskutek wydania przez sąd II instancji orzeczenia kończącego postępowanie.

W uzasadnieniu prezydenckiego projektu ustawy czytamy, że skarga nadzwyczajna będzie mogła być wniesiona od każdego prawomocnego orzeczenia, a więc także od wyroku, który nie był przedmiotem apelacji, oraz od wyroku, który był przedmiotem postępowania kasacyjnego przed SN. Ograniczeniem jest natomiast to, że od tego samego orzeczenia w interesie tej samej strony może być wniesiona tylko jedna skarga nadzwyczajna (art. $90 \S 1$ ustawy o SN). Biorąc to pod uwagę, należy uznać, że w przypadku skargi nadzwyczajnej ustawodawca przewidział bardziej uproszczoną drogę ochrony konstytucyjnych wolności i praw jednostki niż w odniesieniu do skargi konstytucyjnej. W przypadku skargi konstytucyjnej skarżący musi bowiem wykazać, że posiada nie tylko ostateczne orzeczenie wydane w jego sprawie oraz że wyczerpał drogę prawną, tzn. skorzystał z wszystkich przewidzianych prawem instrumentów instancyjnej kontroli tego rozstrzygnięcia. Trybunał wielokrotnie podkreślał, że obowiązek ,wyczerpania drogi prawnej" (art. 46 ust. 1 ustawy o TK z 1997 r.) wyklucza wniesienie skargi konstytucyjnej od takich prawomocnych wyroków, ostatecznych decyzji lub innych ostatecznych rozstrzygnięć, które stały się prawomocne lub ostateczne, dlatego że zainteresowany nie wykorzystał możliwości wyczerpania całego dostępnego toku instancji w postępowaniu sądowym czy administracyjnym. Sformułowanie „orzekł ostatecznie” (art. 79 ust. 1 konstytucji) należy zatem rozumieć jako merytoryczne rozstrzygnięcie (orzeczenie co do istoty), w stosunku do którego nie przysługują środki odwoławcze lub inne środki zaskarżenia, ponieważ zapadło ono ,po wyczerpaniu drogi prawnej”30.

Zgodnie z art. 79 konstytucji skarga konstytucyjna może dotyczyć wyłącznie aktu normatywnego, na podstawie którego sąd lub organ administracji publicznej orzekł ostatecznie o określonych w konstytucji wolnościach, prawach lub obowiązkach skarżącego. Wymienione w ustawie zasadniczej przesłanki skargi konstytucyjnej zostały rozwinięte i sprecyzowane przez ustawodawcę zwykłego w ustawie o TK z 1997 r. ${ }^{31}$

30 Vide np. postanowienie TK z 10 października 2007 r., sygn. akt Ts 91/07, OTK ZU 2007/5B/254.

31 Podobnie przesłanki te doprecyzowano w art. 64 ustawy o TK z 2015 r. i w art. 77 ust. 1 ustawy o TK z 2016 r. 
Odpowiednio do art. 46 ust. 1 ustawy o TK z $1997 \mathrm{r}^{32}$ skarga konstytucyjna może zostać wniesiona w określonym terminie od doręczenia skarżącemu prawomocnego wyroku, ostatecznej decyzji lub innego ostatecznego rozstrzygnięcia. Rozpoznając wniesioną skargę konstytucyjną, należy przede wszystkim odpowiedzieć na pytanie, czy na podstawie zaskarżonych przepisów sąd lub organ administracji publicznej orzekł o konstytucyjnych wolnościach, prawach lub obowiązkach skarżących. Wyrażenie „orzekł ostatecznie" o prawach, wolnościach lub obowiązkach jednostki stanowiło przedmiot wykładni już w pierwszych postanowieniach TK dotyczących skargi konstytucyjnej.

Trybunał zwracał uwagę na fakt, że pojęcia „ostatecznego orzeczenia” nie można ustalić, odwołując się do obowiązującego ustawodawstwa, ponieważ termin ten nie jest powtórzeniem żadnego z ustawowych unormowań proceduralnych. Odmienności terminologiczne ,dają wyraz intencji ustawodawcy konstytucyjnego do użycia pojęcia nowego (odrębnego), o możliwie najogólniejszym charakterze, odnoszącego się do wszelkiego rodzaju końcowych rozstrzygnięć, podejmowanych we wszelkiego rodzaju postępowaniach przed sądami i organami administracji publicznej" (vide np. postanowienie TK z 5 grudnia 1997 r., sygn. akt Ts 14/97, OTK ZU 1998/1, s. 41 oraz postanowienie pełnego składu TK z 4 grudnia 2000 r., sygn. akt SK 10/99, OTK ZU 2000/8/300). Zdaniem TK, aby można było mówić o „ostatecznym orzeczeniu”, działanie organów sądowych i administracyjnych musi mieć władczy charakter i określać sytuację prawną indywidualnie określonego podmiotu. Rozwijając i precyzując konstytucyjne pojęcie „orzeczenia” o wolnościach, prawach lub obowiązkach jednostki, TK stwierdził, że obejmuje ono rozstrzygnięcia, które nakładają, zmieniają lub uchylają obowiązki albo przyznają, zmieniają lub znoszą uprawnienia. Do orzeczeń o wolnościach, prawach lub obowiązkach należy zaliczyć również rozstrzygnięcia, w których autorytatywnie stwierdzono istnienie obowiązku lub uprawnienia, jeżeli rozstrzygnięcia te mają znaczenie dla realizacji określonych uprawnień lub obowiązków jednostki. Do orzeczeń o wolnościach, prawach lub obowiązkach mogą należeć także rozstrzygnięcia polegające na odmowie wydania jednego z wymienionych wcześniej rozstrzygnięć. Trybunał uznawał także, że szczegółowe obowiązki lub uprawnienia jednostki, których dotyczą wymienione rozstrzygnięcia, muszą mieścić się w zakresie wolności, praw lub obowiązków określonych w konstytucji. Podkreślał, że do istoty „orzeczenia o wolnościach, prawach lub obowiązkach” jednostki zawsze należy jego wiążący charakter, wyrażający się w powstaniu, zmianie lub zniesieniu obowiązków ciążących na określonych podmiotach. Podmiotami tymi są zawsze organy władzy publicznej, które realizują określone uprawnienia jednostki lub które egzekwują obowiązki ciążące na jednostce. Takim podmiotem może być również jednostka, należy jednak zauważyć, że nie każde rozstrzygnięcie o wolnościach lub prawach jednostki musi pociągać za sobą powstanie, zmianę lub zniesienie obowiązku ciążącego na osobie fizycznej.

${ }^{32} \mathrm{Na}$ tle przepisów tej ustawy (z racji najdłuższego okresu jej obowiązywania) rozwinęło się bogate orzecznictwo trybunalskie będące także i obecnie - wobec braku zasadniczych zmian dokonywanych przez ustawodawcę $\mathrm{w}$ tym zakresie w kolejnych aktach normatywnych — punktem odniesienia do interpretowania przesłanek określających dopuszczalność skargi konstytucyjnej. 
Nie ulega zatem wątpliwości, że skarga nadzwyczajna w omawianym zakresie będzie stanowić - w porównaniu ze skargą konstytucyjną - mniej sformalizowany instrument ochrony wartości konstytucyjnych, a procedura inicjowania wniesienia skargi nadzwyczajnej będzie mniej czasochłonna. Ponadto perspektywa uzyskania judykatu SN nie będzie tak odległa w czasie jak w przypadku TK ${ }^{33}$. Należy także zwrócić uwagę na inną przesłankę dopuszczalności skargi nadzwyczajnej, tj. wymóg, że orzeczenie, w związku z którym wnosi się ten środek zaskarżenia, nie może zostać uchylone lub zmienione w trybie innych nadzwyczajnych środków zaskarżenia ${ }^{34}$. Jak się wydaje, przesłanka ta w praktyce nie będzie stanowić ograniczenia dla korzystania $\mathrm{z}$ tego środka, inne są bowiem przesłanki wzruszania orzeczeń w trybie nadzwyczajnym, a odmowa przyjęcia kasacji (czy wniosku o wznowienie postępowania) nie ogranicza prawa skazanego do wystąpienia do podmiotów uprawnionych o wniesienie skargi nadzwyczajnej ${ }^{35}$.

Zgodnie z art. 89 § 2 ustawy o SN skargę nadzwyczajną może wnieść prokurator generalny, Rzecznik Praw Obywatelskich ${ }^{36}$, oraz — w zakresie swojej właściwości — prezes Prokuratorii Generalnej RP, Rzecznik Praw Dziecka, Rzecznik Praw Pacjenta, przewodniczący Komisji Nadzoru Finansowego i rzecznik finansowy i prezes Urzędu Ochrony Konkurencji i Konsumentów. W ustawie nie sprecyzowano, w jakim trybie i kto może zwrócić się do podmiotów uprawnionych z inicjatywą wniesienia skargi nadzwyczajnej w konkretnej sprawie. Pewną wskazówką interpretacyjną jest art. 90 $\S 1$ ustawy o SN, zgodnie z którym od tego samego orzeczenia w interesie tej samej strony skarga nadzwyczajna może być wniesiona tylko raz. Wynika z tego, że skargę nadzwyczajną wnosi się w interesie, a nie w imieniu strony. Zatem nie tylko strona postępowania może domagać się wzruszenia orzeczenia w trybie skargi nadzwyczajnej.

${ }^{33}$ W przypadku skarg kasacyjnych i kasacji czas oczekiwania na orzeczenie SN wynosi od trzech miesięcy do roku (K. Żaczkiewicz-Zborska, Coraz więcej zaległości w Sądzie Najwyższym, na stronie internetowej <https://www.prawo.pl>, dostęp 29 VI 2018). Nie są to jednak dane urzędowe. Z informacji o działalności SN wynika jedynie, że czas oczekiwania na rozpoznanie sprawy jest zadowalający (vide Informacja o działalności Sądu Najwyższego w roku 2017, <https:/www.sn.pl>, dostęp 29 VI 2018). Niemniej jest to okres znacznie krótszy niż czas oczekiwania na rozstrzygnięcie TK.

34 Należy podkreślić, że tryby nadzwyczajne (kasacja i skarga kasacyjna w postępowaniu przed $\mathrm{SN}$ ) i ewentualna możliwość wznowienia postępowania zakończonego prawomocnym wyrokiem w kontekście dopuszczalności wniesienia skargi konstytucyjnej nie mają znaczenia. Orzeczenie prawomocne jest zatem orzeczeniem, którego nie można już zaskarżyć w drodze zwykłych środków odwoławczych (vide np. postanowienie TK z 21 grudnia 2010 r., sygn. akt Ts 16/10, OTK ZU 2014/IIB/798).

35 Postanowienie SN Izba Karna z 14 czerwca 2018 r., sygn. akt II KZ 19/18.

36 Należy zauważyć, że zgodnie z art. 521 k.p.k. RPO może wnieść kasację od każdego prawomocnego orzeczenia sądu kończącego postępowanie. Natomiast Rzecznik Praw Dziecka może wnieść kasację od każdego prawomocnego orzeczenia sądu kończącego postępowanie, jeżeli przez wydanie orzeczenia doszło do naruszenia praw dziecka. Jednocześnie zgodnie z art. $398^{1}$ k.p.c. od wydanego przez sąd II instancji prawomocnego wyroku lub postanowienia w przedmiocie odrzucenia pozwu albo umorzenia postępowania kończących postępowanie w sprawie stron prokurator generalny, RPO lub Rzecznik Praw Dziecka może wnieść skargę kasacyjną do SN, chyba że przepis szczególny stanowi inaczej. Wniesienie skargi kasacyjnej przez stronę wyłącza jednak — w zaskarżonym zakresie — wniesienie skargi kasacyjnej przez prokuratora generalnego, RPO lub Rzecznika Praw Dziecka. 
Co więcej - choć wydaje się to mało prawdopodobne - podmioty uprawnione do bezpośredniego wniesienia tego środka będą mogły działać w tym zakresie z urzędu.

Skarga nadzwyczajna będzie miała zatem szerszy zakres zastosowania niż skarga konstytucyjna. Podmiotem uprawnionym do korzystania $\mathrm{z}$ tego drugiego środka ochrony jest bowiem wyłącznie ten, czyje konstytucyjne wolności lub prawa doznały rzeczywistego i bezpośredniego naruszenia wskutek zastosowania kwestionowanej regulacji ustawy lub innego aktu normatywnego (vide postanowienie TK z 15 lutego 2012 r., sygn. akt Ts 318/11, OTK ZU 2013/1B/97). Ponadto prawa konstytucyjne, których ochrony chce się dochodzić w trybie skargi konstytucyjnej, muszą przysługiwać bezpośrednio podmiotowi, który występuje do TK z tym środkiem prawnym. Legitymowana do wniesienia skargi konstytucyjnej jest bowiem wyłącznie ta osoba, która jest podmiotem naruszonego prawa lub wolności o charakterze konstytucyjnym. Nie ma zatem możliwości wnoszenia skargi konstytucyjnej jako actio popularis (vide postanowienie TK z 13 lipca 2005 r., sygn. akt Ts 85/05, OTK ZU 2005/4B/178).

Natomiast w przypadku skargi nadzwyczajnej z żądaniem jej wniesienia będzie mógł wystąpić - na co wskazuje literalna wykładnia odpowiednich przepisów ustawy o SN — np. pokrzywdzony nieusatysfakcjonowany wyrokiem sądu karnego lub organizacja pozarządowa, która nie uczestniczyła w sprawie w postępowaniu cywilnym. Jednocześnie należy wskazać, że zarówno w przepisach kodeksu postępowania cywilnego, jak i w odpowiednich regulacjach kodeksu postępowania karnego przewidziano prawo wglądu do akt sprawy. Zgodnie z art. 156 § 1 k.p.k., stronom, obrońcom, pełnomocnikom i przedstawicielom ustawowym udostępnia się akta sprawy sądowej oraz daje możność sporządzenia z nich odpisów lub kopii. Za zgodą prezesa sądu akta te mogą być udostępnione również innym osobom. Odpowiednio do art. 9 § 1 k.p.c. rozpoznawanie spraw jest jawne, chyba że przepis szczególny stanowi inaczej. Strony i uczestnicy postępowania mają prawo przeglądać akta sprawy i otrzymywać odpisy, kopie lub wyciągi $\mathrm{z}$ tych akt. W postępowaniu nieprocesowym akta sprawy dostępne są dla uczestników postępowania oraz za zezwoleniem przewodniczącego dla każdego, kto potrzebę przejrzenia dostatecznie usprawiedliwi. Na tych samych zasadach dopuszczalne jest sporządzanie i otrzymywanie odpisów i wyciągów z akt sprawy oraz otrzymywanie zapisu dźwięku albo obrazu i dźwięku z akt sprawy (art. 525 k.p.c.). Natomiast Naczelny Sąd Administracyjny w uchwale z 9 grudnia 2013 r. (sygn. akt I OPS 7/13) uznał że żądanie udostępnienia akt sprawy jako całości, także akt zakończonego postępowania przygotowawczego, nie jest wnioskiem o udostępnienie informacji publicznej, ale żądaniem udostępnienia określonego zbioru materiałów. Zatem tak sformułowany wniosek nie wskazuje na informacje publiczne, których udostępnienia domaga się wnioskodawca i nie może zostać uwzględniony na podstawie przepisów ustawy z dnia 6 września $2001 \mathrm{r}$. o dostępie do informacji publicznej (Dz.U. z 2016 r. poz. 1764, ze zm.). Jednocześnie w wyroku z 19 grudnia 2017 r. (sygn. akt I OSK 1003/17) NSA potwierdził, że uchwała ta dotyczyła kwestii nieokreślonego bliżej żądania udostępnienia całości akt sprawy jako zbioru materiałów, odnosiła się zatem do odrębnej instytucji uregulowanej w przepisach procesowych. Wyrażone w niej stanowisko nie ma natomiast zastosowania w odniesieniu 
do wniosku o informację publiczną znajdującą się w aktach sprawy w postaci konkretnego dokumentu (np. orzeczenia).

Dostęp do orzeczeń wydawanych w postępowaniach karnych i cywilnych można zatem uzyskać w trybie dostępu do informacji publicznej. Jednocześnie, skoro skargi nadzwyczajnej nie musi wnosić strona postępowania, można wyobrazić sobie sytuację, w której każdy potencjalny obywatel będzie mógł wnieść do uprawnionego podmiotu żądanie wniesienia takiej skargi w odniesieniu do dowolnego orzeczenia wydanego przez sąd powszechny lub wojskowy, z zastrzeżeniem ram czasowych ich wzruszania określonych w ustawie o SN. Z wielkim prawdopodobieństwem należy więc przypuszczać, że zwłaszcza w początkowej fazie funkcjonowania skarga nadzwyczajna będzie postrzegana przez różnego rodzaju kwerulantów sądowych jako kolejny instrument walki z wymiarem sprawiedliwości. Tym większego znaczenia nabiera zatem wypracowanie przez wszystkie podmioty uprawnionego do wnoszenia skarg nadzwyczajnych jednolitej interpretacji pojęć ustawowych określających przesłanki dopuszczalności tego środka.

Skargi nadzwyczajnej nie można oprzeć na zarzutach, które były przedmiotem rozpoznawania przez SN przy rozpatrywaniu skargi kasacyjnej lub kasacji (art. 90 § ustawy o SN). Należy więc rozważyć, czy w sytuacji gdy w skardze kasacyjnej (kasacji) podnoszono zarzuty natury konstytucyjnej (a szczególnie, gdy sformułowano wniosek o skierowanie pytania prawnego do TK $)^{37}$, a SN niepodzielający tych wątpliwości skarżącego

${ }^{37}$ Może także dojść do sytuacji, w której sąd skieruje pytanie prawne do TK, ale Trybunał postępowanie w tej sprawie umorzy. Czy taki bieg postępowania będzie miał znaczenie w kontekście dopuszczalności skargi nadzwyczajnej? Warto przywołać sprawę zakończoną wyrokiem SN z 15 września 2017 r. (sygn. akt III CSK 241/16). Sprawa zawisła przed Sądem Okręgowym w Krakowie dotyczyła wniosku powoda o wydanie orzeczenia stwierdzającego obowiązek Gminy Wyznaniowej Żydowskiej [dalej: GWŻ] w Krakowie, zastępującego jej oświadczenie o przyjęciu powoda w poczet jej członków. Podstawą prawną powództwa był art. 64 ustawy z dnia 23 kwietnia 1964 r. - Kodeks cywilny (Dz.U. z 2014 r. poz. 121; dalej: k.c.), który brzmi: „Prawomocne orzeczenie sądu stwierdzające obowiązek danej osoby do złożenia oznaczonego oświadczenia woli, zastępuje to oświadczenie”. Sąd zwrócił się do TK z następującym pytaniem prawnym: „Czy przepis art. 2 ust. 1 ustawy z dnia 20 lutego 1997 r. o stosunku Państwa do gmin wyznaniowych żydowskich w Rzeczypospolitej Polskiej (Dz.U. nr 41, poz. 251, ze zm.; dalej: u.g.w.ż.) jest zgodny z art. 32 w związku z art. 53 ust. 1 i 2 Konstytucji Rzeczypospolitej Polskiej w zakresie, w jakim uniemożliwia pełnoletnim osobom wyznania mojżeszowego, zamieszkującym na terenie Rzeczypospolitej, lecz nieposiadającym obywatelstwa polskiego, przyjęcie w poczet członków gminy wyznaniowej”, zawieszając postępowanie do czasu rozstrzygnięcia sprawy przez TK. Trybunał postanowieniem z 18 lutego 2015 r., sygn. akt P 48/13 (OTK ZU 2015/2A/22), umorzył postępowanie ze względu na niedopuszczalność wydania wyroku. Uznał, że w sprawie zawisłej przed Sądem Okręgowym w Krakowie brak jest podstaw prawnych do uznania istnienia cywilnoprawnego obowiązku GWŻ w Krakowie przyjęcia powoda w poczet swych członków. Pytanie prawne sądu nie spełniało zatem przesłanki funkcjonalnej, ponieważ udzielenie odpowiedzi przez Trybunał na to pytanie nie było warunkiem podjęcia przez sąd rozstrzygnięcia z zastosowaniem kwestionowanego przepisu u.g.w.ż. Stwierdzenie niekonstytucyjności art. 2 ust. 1 u.g.w.ż. w zakwestionowanym zakresie nie przesądziłoby również o uwzględnieniu powództwa. Do postanowienia TK zdanie odrębne zgłosił sędzia W. Hermeliński, który nie zgodził się z tym rozstrzygnięciem. Jednocześnie postanowieniem z 18 lutego 2015 r., sygn. akt S 2/15 (OTK ZU 2015/2A/23) TK przedstawił Sejmowi uwagi o stwierdzonym uchybieniu w art. 2 ust. 1 u.g.w.ż. co do polskiego obywatelstwa jako ustawowego kryterium dopuszczalności członkostwa w gminach wyznaniowych żydowskich, uznając, że usunięcie tego kryterium jest niezbędne w celu zapewnienia spójności systemu 
nie przychylił się do wniosku, w skardze nadzwyczajnej należy podnieść innego rodzaju wątpliwości. Za niepodważalną należy przy tym uznać kompetencję sądu do oceny, czy zakwestionowany przepis nasuwa wątpliwości konstytucyjne, czy też nie, oraz do dokonania takiej jego interpretacji, która zapewnia zgodność z ustawą zasadniczą ${ }^{38}$.

Należy podkreślić, że do niedawna akceptowano w orzecznictwie interpretację, zgodnie z którą sądy oraz organy stosowania prawa nie mają kompetencji do orzekania o niekonstytucyjności przepisu ustawy i odmowy jego zastosowania. Domniemanie zgodności ustawy z konstytucją, które można obalić jedynie w wyroku TK ${ }^{39}$,

prawnego RP. W konsekwencji sąd okręgowy oddalił powództwo, a sąd apelacyjny wniesioną od wyroku sądu okręgowego apelację. Rozpatrując skargę kasacyjną, SN podniósł, że „interpretacja art. 2 ust. 1 ustawy z dnia 20 lutego 1997 r., zgodnie z którą przepis ten przewiduje powstanie ex lege członkostwa w gminie wyznaniowej [...], pozostawałaby w sprzeczności z art. 53 Konstytucji dotyczącym wolności sumienia i wyznawania religii, a ściślej z przepisami art. 2 pkt 1 i 2a ustawy z dnia 17 maja 1989 r. o gwarancjach wolności sumienia i wyznania (tekst jedn.: Dz.U. z 2017 r. poz. 1153), według których korzystanie z wolności sumienia i wyznania obejmuje w szczególności możność tworzenia wspólnot religijnych, zwanych «kościołami i innymi związkami wyznaniowymi», oraz należenia lub nienależenia do kościołów i innych związków wyznaniowych. Osoba wyznania mojżeszowego może więc, według swojego wyboru, albo należeć do jednej z wyznaniowych gmin żydowskich, zrzeszonych w Związku Gmin Wyznaniowych Żydowskich w Rzeczypospolitej Polskiej, albo należeć do innego związku wyznaniowego, albo nie należeć do żadnego związku”. Dodał także, uchylając wyroki sądów I i II instancji, że kwestia wyboru np. członków zarządu nie podlega sądowej kontroli merytorycznej zarówno w gminach wyznaniowych, jak i w takich korporacjach, jak spółdzielnie czy spółki kapitałowe i stanowi dyskrecjonalne uprawnienie właściwego organu. Natomiast stosownej kontroli mogą podlegać kwestie związane z członkostwem w Kościele lub innym związku wyznaniowym. Stosunek członkostwa ma niewątpliwie charakter cywilnoprawny, skoro Kościół (inny związek wyznaniowy) ma osobowość prawną jako całość lub mają ją jego wyodrębnione jednostki, a prawo wewnętrzne Kościoła (innego związku wyznaniowego) jest statutem osoby prawnej w rozumieniu art. 35 i 38 k.c. (vide uchwała SN z 19 grudnia 2008 r., sygn. akt III CZP 122/08, postanowienie SN z 12 stycznia 2011 r., sygn. akt CSK 182/10, wyrok SN z 13 kwietnia 2012 r., sygn. akt I CSK 451/11). Tym samym SN podważył stanowisko TK przedstawione w postanowieniu z 18 lutego 2015 r., w którym TK uznał, że pragnącym przystąpić do tej wspólnoty nie przysługuje roszczenie cywilnoprawne na mocy art. 2 ust. 1 u.g.w.ż.

${ }^{38}$ L. Garlicki, Sądy a Konstytucja Rzeczypospolitej Polskiej, „Przegląd Sądowy” 2016, nr 7-8, s. 15.

${ }^{39}$ Za interesujący w omawianym zakresie należy uznać wyrok SN z 17 marca 2016 r., sygn. akt V CSK 337/15, oraz wyrok NSA z 12 kwietnia 2016 r., sygn. akt II FSK 330/15, oba dotyczące przepisu art. 70 ordynacji podatkowej i nawiązujące do wyroku TK z 8 października 2013 r. (sygn. akt SK 40/12, OTK ZU 2013/7A/97), w którym uznano niekonstytucyjność przepisu o niemal identycznej treści, tyle że dotyczącego innego okresu. Co więcej, TK wskazał też na konieczność dokonania zmiany w przepisie, który stał się przedmiotem oceny SN i NSA. W obu tych orzeczeniach stwierdzono, że wyrok TK uznający niekonstytucyjność przepisu ustawy daje sądowi podstawę do odmowy zastosowania identycznego treściowo przepisu, nawet jeżeli nie był on bezpośrednim przedmiotem orzekania przez TK. Odmiennie orzekł NSA w postanowieniu z 6 sierpnia 2014 r., sygn. akt II FSK 115/14, w którym odrzucił skargę podatników i wyjaśnił, że moc wiążącą mają tylko rozstrzygnięcia zawarte w sentencji wyroku TK. Sentencja wyroku Trybunału z 8 października 2013 r., zgodnie z zasadą skargowości, dotyczy tylko przepisu, który został zaskarżony w postępowaniu przed TK (w sprawie o sygn. SK 40/12 był nim art. 70 § 6 ordynacji podatkowej). W konsekwencji podstawą wznowienia postępowania nie mogą być wywody zawarte w uzasadnieniu wyroku TK w sprawie o sygn. SK 40/12, dotyczące zastrzeżeń co do konstytucyjności art. 70 $\S 8$ ordynacji podatkowej obowiązującego od 1 stycznia 2003 r., tj. przepisu, który nie był przedmiotem orzekania w sprawie o sygn. SK 40/12. Wyrok Trybunału nie dotyczy zatem przepisu art. $70 § 8$ ordynacji podatkowej, który był podstawą wydanych wobec skarżących decyzji administracyjnych, poddanych następnie kontroli sądowoadministracyjnej. 
oraz związanie sędziego ustawą, o którym mowa w art. 178 ust. 1 konstytucji, obowiązuje dopóty, dopóki ustawa ta obowiązuje. Jeżeli sąd jest przekonany o niezgodności przepisu z konstytucją lub ma w tym względzie wątpliwości, powinien - na podstawie art. 193 konstytucji — zwrócić się do TK z odpowiednim pytaniem prawnym ${ }^{40}$. Należy przy tym podkreślić, że — zgodnie $\mathrm{z}$ tą koncepcją — jednocześnie nie neguje się tzw. wykładni prokonstytucyjnej na podstawie odczytywania norm zawartych w przepisach ustawowych, przy uwzględnianiu właściwych dla danej części systemu prawa wzorców konstytucyjnych, od której należy odróżnić wykładnię ustaw w zgodzie z konstytucją ${ }^{41}$. Syntetycznie kwestię tę ujął Piotr Tuleja, podkreślając, że „nieco inna jest funkcja wykładni ustaw w zgodzie z Konstytucją, gdy posługuje się nią TK w procesie kontroli konstytucyjności prawa, a inna, gdy odwołują się do niej sądy realizujące wymiar sprawiedliwości. W pierwszym przypadku chodzi przede wszystkim o ustalenie wiążącego dla innych organów znaczenia przepisu ustawy na poziomie generalno-abstrakcyjnym, w drugim — o ustalenie normatywnej treści ustawy będącej podstawą dla konkretno-indywidualnej normy" ${ }^{\prime 2}$.

W tym znaczeniu model związany z konstytucyjną kompetencją sądów powszechnych do współstosowania konstytucji i ustaw oraz powinności stosowania prokonstytucyjnej wykładni nie stanowi zagrożenia dla funkcji TK, w żaden sposób nie wpływa bowiem na proces abstrakcyjnej hierarchicznej kontroli norm, pozostający w wyłącznej kompetencji Trybunału, oraz nie prowadzi do zakwestionowania tej kompetencji w przedmiocie usuwania w sposób powszechnie obowiązujący niezgodnych z konstytucją aktów normatywnych z porządku prawnego $\mathrm{RP}^{43}$. Należy więc wskazać, że kompetencje SN przyznane ustawą o SN stanowią w tym zakresie swego rodzaju novum. Konstatacja ta wpływa na postrzeganie kognicji SN w sprawach skarg nadzwyczajnych jako kontroli konstytucyjności nie prawa stanowionego, ale procesu jego stosowania w formie wydawanych przez sądy powszechne i wojskowe orzeczeń (skarga na stosowanie prawa).

Biorąc przedstawione rozważania pod uwagę — w moim przekonaniu — nie można uznać, że podniesiony w skardze kasacyjnej (kasacji) zarzut niekonstytucyjności przepisów stanowiących podstawę orzekania przez sądy I i II instancji, a powiązany następnie w skardze nadzwyczajnej z tymi samymi wzorcami konstytucyjnymi jest zarzutem tożsamym. W trybie skargi kasacyjnej (kasacji) SN mógł bowiem dokonać wyłącznie prokonstytucyjnej (zgodnej z konstytucją) wykładni regulacji prawa stanowionego lub skierować pytanie prawne do TK, natomiast w trybie skargi nadzwyczajnej będzie kontrolował zgodność orzeczenia - zwłaszcza dokonanej przez sąd wykładni przepisów, nie zaś jego podstaw prawnych - z określonymi wartościami zawartymi w ustawie zasadniczej. W tym znaczeniu kontrola zainicjowana skarga nadzwyczajną będzie miała

40 Vide wyrok TK z 10 grudnia 2002 r., sygn. akt P 6/02, OTK ZU 2002/7A/91 i wyrok SN z 24 listopada 2015 r., sygn. akt II CSK 517/14.

${ }^{41}$ Szerzej na ten temat vide M. Gutowski, P. Kardas, Sądowa kontrola konstytucyjności prawa. Kilka uwag o kompetencjach sądów powszechnych do bezpośredniego stosowania konstytucji, „Palestra” 2016, nr 4, s. 5-30.

42 P. Tuleja, Stosowanie Konstytucji RP w świetle zasady jej nadrzędności, Kraków 2003, s. 307 i n.

43 M. Gutowski, P. Kardas, Sądowa kontrola..., s. 5-30. 
szerszy kontekst. Należy zatem zwrócić uwagę na dotychczasowe orzecznictwo TK, zgodnie z którym przedmiotem badania TK nie są akty stosowania prawa, a więc prawomocne orzeczenia lub ostateczne decyzje zapadłe $\mathrm{w}$ indywidualnych sprawach, ale wyłącznie akty normatywne, na podstawie których rozstrzygnięcia te zostały wydane. Zadaniem Trybunału jest bowiem orzekanie w sprawach zgodności z konstytucją aktów normatywnych, mające na celu wyeliminowanie z systemu prawnego przepisów prawa, które z konstytucją są niezgodne. Nie ulega zatem wątpliwości, że jedynym dopuszczalnym przedmiotem skargi konstytucyjnej w polskim prawie jest przepis prawny wykazujący dwojaką kwalifikację: po pierwsze - wydane przez sąd lub organ administracji publicznej ostateczne orzeczenie naruszające konstytucyjne prawa lub wolności podmiotu występującego ze skargą; po drugie - bezpośrednia przyczyna takiego naruszenia powinna tkwić w normatywnej treści kwestionowanego przepisu. Chociaż więc uprzedni akt stosowania przepisu będącego przedmiotem skargi nie pozostaje bez znaczenia w kontekście dopuszczalności korzystania z tego środka ochrony, to jednak nie ostateczne orzeczenie wydane na jego podstawie, ale sam przepis prawny będący taką podstawą stanowi jedyny dopuszczalny przedmiot skargi konstytucyjnej. Innymi słowy, niedopuszczalna jest skarga konstytucyjna skierowana wyłącznie przeciwko orzeczeniu wydanemu w sprawie skarżącego, tzw. skarga na stosowanie prawa ${ }^{44}$.

$\mathrm{Z}$ przedstawionych względów skarga nadzwyczajna niewątpliwie z założenia wzmacnia standard ochrony konstytucyjnych wolności i praw jednostki w takim zakresie, w jakim są one związane z normami prawa cywilnego i karnego. Zgodnie z art. 79 ust. 1 konstytucji skargę konstytucyjną może wnieść „każdy, czyje konstytucyjne wolności lub prawa zostały naruszone". Oznacza to, że warunkiem złożenia skargi konstytucyjnej nie jest każde naruszenie konstytucji, ale tylko naruszenie wyrażonych w niej norm regulujących wolności lub prawa człowieka i obywatela. W skardze konstytucyjnej trzeba zatem wskazać zarówno konkretną osobę, której wolności lub prawa naruszono, jak i te wolności i prawa (poręczone, zapewnione, gwarantowane, chronione) określone w konstytucji, które naruszono, a także określić sposób tego naruszenia ${ }^{45}$. Niemniej legitymowaną do wniesienia skargi konstytucyjnej jest wyłącznie ta osoba, która jest podmiotem naruszonego prawa lub wolności o charakterze konstytucyjnym.

Natomiast w ustawowej regulacji skargi nadzwyczajnej zaakcentowano związek między prawomocnym orzeczeniem a naruszeniem zasad lub wolności oraz praw człowieka i obywatela określonych w konstytucji. Jednocześnie w celu skorzystania z tego środka ochrony nie wymaga się: po pierwsze, bycia stroną w sprawie, w której wydano prawomocne orzeczenie (podmioty legitymowane do wniesienia skargi nadzwyczajnej mogą zatem działać z inicjatywy własnej lub osób trzecich), a po drugie — bycia podmiotem naruszonych wartości konstytucyjnych (skarga nadzwyczajna może zatem

44 Vide np. postanowienie TK z 21 marca 2006 r., sygn. akt Ts 49/06, OTK ZU 2006/5B/237. Niedopuszczalna jest więc taka skarga konstytucyjna, w której przedstawione zarzuty dotyczą wykładni dokonanej przez sąd, błędnej subsumpcji stanu faktycznego czy też wadliwości kierunku argumentacji wykorzystanej w ostatecznym orzeczeniu (tzw. skarga na stosowanie prawa; vide postanowienie TK z 2 grudnia 2010 r., sygn. akt SK 11/10, OTK ZU 2010/10A/131.

45 Vide postanowienie TK z 30 kwietnia 2014 r., sygn. akt Ts 73/14, OTK ZU 2014/4B/362. 
zostać wniesiona w interesie osób trzecich, a nie stron postępowania, w którym zapadło prawomocne orzeczenie). $\mathrm{Z}$ tych powodów katalog wolności i praw konstytucyjnych, które będą stanowić wzorce kontroli, w przypadku skargi nadzwyczajnej będzie niezwykle szeroki, a przede wszystkim będzie mógł pozostać niezależny od inicjatora wniesienia skargi nadzwyczajnej oraz stron postępowania, w którym zapadło skarżone orzeczenie. Ponadto — odmiennie niż w przypadku skargi konstytucyjnej — wzorcami kontroli będą także zasady konstytucyjne, a zatem unormowania konstytucyjne o charakterze aksjologicznym. Zawarte są one przede wszystkim w I rozdziale konstytucji, zatytułowanym „Rzeczpospolita” i określają ustrój polityczny, gospodarczy i społeczny państwa. Zasady te odnaleźć można także w innych regulacjach konstytucyjnych (w szczególności w rozdziale II). Należy też pamiętać, że podstawowe zasady wyrażone w ustawie zasadniczej można odnaleźć także w treści preambuły do konstytucji. W tym kontekście należy też podkreślić, że takie ujęcie skargi nadzwyczajnej umożliwi SN traktowanie m.in. zasady demokratycznego państwa prawnego, zasady równości i zasady proporcjonalności jako samodzielnych wzorców kontroli ${ }^{46}$. Niemniej takim

${ }^{46} \mathrm{Na}$ temat możliwości powoływania się na naruszenie art. 2 konstytucji w skardze konstytucyjnej TK wypowiadał się wielokrotnie, a najpełniej w sprawie o sygn. akt Ts 105/00 (postanowienia TK z 12 grudnia 2000 r. oraz 23 stycznia 2002 r., OTK ZU 2002/1B/59 i 60). Trybunał badał, czy możliwe jest dochodzenie ochrony zasad wynikających z art. 2 ustawy zasadniczej w trybie skargi konstytucyjnej. Zwrócił uwagę zwłaszcza na konieczność precyzyjnego określenia wolności lub prawa podmiotowego (wyinterpretowanych z przepisu), których naruszenie ma uzasadnić legitymację do wniesienia skargi konstytucyjnej. Trybunał podkreślił przy tym, że chodzi tu o prawa lub wolności przyjmujące normatywną formę praw podmiotowych. To znaczy o prawa, których adresatem jest obywatel (lub inny podmiot prawa) i które kształtują jego sytuację prawną oraz dają mu możliwość wyboru zachowania się, tj. spełnienia lub niespełnienia normy prawnej. Powołanie się na naruszenie - wynikającej z art. 2 konstytucji — zasady sprawiedliwości społecznej nie jest podstawą do wniesienia skargi, ponieważ zasada ta ma charakter przedmiotowy, jest adresowana do ustawodawcy i wyznacza sposób regulowania poszczególnych dziedzin życia publicznego. Trybunał podkreślił, że odwołanie się do niej (a także pozostałych, wywodzonych z zasady demokratycznego państwa prawnego) może mieć znaczenie tylko wtedy, gdy skarżący wskaże równocześnie wolność lub prawo podmiotowe mające swoje źródło w innym przepisie konstytucji i jest ograniczone wskutek naruszenia wymienionych zasad (vide postanowienia TK z: 19 grudnia 2001 r., sygn. akt SK 8/01, OTK ZU 2001/8/272; 26 czerwca 2002 r., sygn. akt SK 1/02, OTK ZU 2002/4A/53 oraz 1 października 2003 r., sygn. akt SK 29/02, OTK ZU 2003/8A/87). Na temat charakteru normy określonej w art. 32 konstytucji Trybunał wypowiedział się w wydanym w pełnym składzie postanowieniu z 24 października $2001 \mathrm{r}$. W sprawie o sygn. akt SK 10/01 TK orzekł, że ,,art. 32 Konstytucji wyraża przede wszystkim zasadę ogólną, i dlatego winien być w pierwszej kolejności odnoszony do konkretnych przepisów Konstytucji, nawet jeżeli konstytucyjna regulacja danego prawa jest niepełna i wymaga konkretyzacji ustawowej. W takim zakresie wyznacza on także konstytucyjne prawo do równego traktowania. Mamy tu do czynienia z sytuacją «współstosowania» dwóch przepisów Konstytucji, a więc nie tylko z prawem do równego traktowania, ale ze skonkretyzowanym prawem do równej realizacji określonych wolności i praw konstytucyjnych. W skardze konstytucyjnej należy powołać oba przepisy Konstytucji, dopiero one wyznaczają bowiem konstytucyjny status jednostki, który przez regulację ustawową lub podustawową został naruszony. Natomiast gdy chodzi o uprawnienia określone w innych niż Konstytucja aktach normatywnych — jeśli treść konkretnego prawa ustala się wyłącznie na ich podstawie art. 32 Konstytucji stanowi zasadę systemu prawa, a nie wolność lub prawo o charakterze konstytucyjnym" (OTK ZU 2001/7/225). Trzeci ze wskazanych wzorców kontroli, tj. art. 33 konstytucji, jest rozwinięciem i konkretyzacją ogólnej zasady równości, w związku z czym przytoczone argumenty odnoszą się także do niego (postanowienie TK z 30 kwietnia 2014 r., sygn. akt Ts 73/14, OTK ZU 2014/4B/362). 
wzorcem będą również zasady: bezpieczeństwa prawnego, bezpieczeństwa obywateli, równowagi budżetowej, dobra wspólnego. Biorąc zatem pod uwagę szeroki katalog wartości konstytucyjnych, na które może powołać się wnoszący skargę nadzwyczajną, żądając wzruszenia ostatecznego orzeczenia, pozytywnie należy ocenić wprowadzenie przez ustawodawcę dodatkowej przesłanki, której wystąpienie umożliwi uchylenie tego judykatu, tj. konieczności zapewnienia zgodności z zasadą demokratycznego państwa prawnego urzeczywistniającego zasady sprawiedliwości społecznej, które to wartości — co istotne — także stanowią zasady konstytucyjne.

Zasada demokratycznego państwa prawa stanowi podstawę ustroju politycznego Polski. Stanowi ona źródło nie tylko pozostałych zasad zawartych w konstytucji, ale zawiera w sobie inne niewyrażone wprost w przepisach ustawy zasadniczej komponenty, jak: zasada niedziałania prawa wstecz, zasada ochrony praw słusznie nabytych czy zasada zaufania do państwa i stanowionego przez nie prawa. Natomiast zasada sprawiedliwości społecznej z jednej strony generuje sama z siebie nakaz urzeczywistniania przez organy państwowe zasad sprawiedliwości społecznej, z drugiej — obejmuje konglomerat tych zasad (norm) o charakterze materialnym i proceduralnym oraz wspólną im wszystkim wartość w formie imperatywu sprawiedliwego działania władz publicznych i uwzględniania wymogu sprawiedliwości w kształtowaniu treści wydawanych przez nie aktów prawnych ${ }^{47}$. Mimo że TK od początku swojej działalności często sięgał i wciąż sięga do zasad sprawiedliwości społecznej jako podstawy swoich orzeczeń, a w konstytucji nie zdefiniowano tego zwrotu, w doktrynie prawa nadal brakuje precyzyjnego, a przede wszystkim jednoznacznego określenia treści tych zasad. Zatem stwierdzenie, że prawomocne orzeczenie narusza konstytucyjne zasady, wolności lub prawa jednostki nie będzie wystarczające do jego uchylenia. Sąd Najwyższy — a wcześniej podmiot wnoszący skargę nadzwyczajną — będzie musiał zatem także wykazać, że wzruszenie takiego orzeczenia jest konieczne w celu zapewnienia zarówno zasady demokratycznego państwa prawnego, jak i sprawiedliwości społecznej.

\section{WNIOSKI}

Pierwsze głosy rozczarowania funkcjonowaniem skargi konstytucyjnej — po nadziejach związanych z wprowadzeniem tej instytucji — pojawiły się już w 1997 r. Wynikało to przede wszystkim z rozbieżności między oczekiwaniami a realnym kształtem skargi konstytucyjnej, jak również krótką praktyką stosowania nowych regulacji. Dopiero w kolejnych latach liczba skarg kierowanych do TK zaczęła wzrastać. Trybunał orzekając w konkretnych sprawach, rozstrzygnął wiele istotnych $\mathrm{z}$ punktu widzenia obywateli zagadnień konstytucyjnych, nierzadko formułując w stosunku do ustawodawcy fundamentalne i brzegowe warunki zgodności procesu tworzenia prawa z konstytucją. Niemniej praktyka związana z funkcjonowaniem skargi konstytucyjnej skłania do negatywnej oceny tej instytucji.

${ }^{47}$ A. Domańska, Zasady sprawiedliwości społecznej we współczesnym polskim prawie konstytucyjnym, Łódź 2001, s. 138. 
Skarga nadzwyczajna jest niewątpliwie instrumentem naruszającym zasadę zaufania do państwa i stanowionego przez nie prawa, godzi w stabilność orzecznictwa oraz w zasadę powagi rzeczy osądzonej, a określenie całokształtu negatywnych skutków jej wprowadzenia do systemu prawa w tej chwili nie jest możliwe. Za konieczne i pożądane należy zatem uznać zmiany, jakie w modelu skargi nadzwyczajnej wprowadzono ustawą z dnia 10 maja 2018 r. o zmianie ustawy — Prawo o ustroju sądów powszechnych, ustawy o Sądzie Najwyższym oraz niektórych innych ustaw (Dz.U. poz. 1045), a zwłaszcza te, które ograniczyły możliwość wnoszenia tych skarg w odniesieniu do orzeczeń, które uprawomocniły się przed jej wejściem w życie.

$\mathrm{Na}$ kompleksową ocenę wprowadzenia skargi nadzwyczajnej do systemu polskiego prawa jednak trzeba poczekać. Nie można przy tym tracić z pola widzenia obaw i wątpliwości, które zgłaszano wobec tego instrumentu w toku prac legislacyjnych. W konsekwencji organy, za pośrednictwem których można wnieść skargę nadzwyczajną oraz SN, powinny zwrócić szczególną uwagę na wypracowanie tożsamej wykładni niedookreślonych i ocennych pojęć, które definiują przesłanki umożliwiające skorzystanie $\mathrm{z}$ tego środka ochrony konstytucyjnych praw i wolności. Biorąc pod uwagę mnogość podmiotów inicjujących postępowanie przed SN, może to być utrudnione, więc tym większa w tym zakresie rola doktryny. Niemniej w przypadku, gdyby skarga ta stała się uzupełnieniem skargi konstytucyjnej w tych obszarach, gdzie ta druga — z racji ograniczeń prawnych lub praktycznych — nie może być efektywna, należy postulować objęcie tą (lub podobną instytucją) postępowań w sprawach administracyjnych.

BIBLIOGRAFIA

ŹRÓDŁA

Ustawa z dnia 17 listopada 1964 r. - Kodeks postępowania cywilnego, (Dz.U. z 2016 r. poz. 1822 , ze zm.).

Ustawa z dnia 6 czerwca 1997 r. — Kodeks postępowania karnego (Dz.U. z 2017 r. poz. 1904, ze zm.).

Ustawa z dnia 1 sierpnia 1997 r. o Trybunale Konstytucyjnym (Dz.U. nr 102, poz. 643, ze zm.).

Ustawa z dnia 25 czerwca 2015 r. o Trybunale Konstytucyjnym (Dz.U. poz. 1064).

Ustawa z dnia 22 lipca 2016 r. o Trybunale Konstytucyjnym (Dz.U. poz. 1157).

Ustawa z dnia 13 grudnia 2016 r. - Przepisy wprowadzające ustawę o organizacji i trybie postępowania przed Trybunałem Konstytucyjnym oraz ustawę o statusie sędziów Trybunału Konstytucyjnego (Dz.U. poz. 2074).

Ustawa z dnia 30 listopada 2016 r. o statusie sędziów Trybunału Konstytucyjnego (Dz.U. poz. 2073).

Ustawa z dnia 30 listopada 2016 r. o organizacji i trybie postępowania przed Trybunałem Konstytucyjnym (Dz.U. poz. 2072).

Informacja o istotnych problemach wynikających z działalności i orzecznictwa Trybunatu Konstytucyjnego w 2016 r., <http://trybunal.gov.pl>, Warszawa 2016.

Informacja o działalności Sądu Najwyższego w roku 2017, <https://www.sn.pl>, Warszawa 2018. 


\section{ORZECZNICTWO}

Wy roki T K

Wyrok TK z 12 listopada 2002 r., sygn. akt SK 40/01, OTK ZU 2002/6A/81.

Wyrok TK z 10 grudnia 2002 r., sygn. akt P 6/02, OTK ZU 2002/7A/91.

Wyrok TK z 22 listopada 2005 r., sygn. akt SK 8/05, OTK ZU nr 2005/10A/117.

Wyrok TK z 24 października 2007 r., sygn. akt SK 7/06, OTK ZU 2007/9A/108.

Wyrok TK z 26 maja 2008 r., sygn. akt SK 25/07, OTK ZU 2008/4A/62.

Wyrok TK z 8 października 2013 r., sygn. akt SK 40/12, OTK ZU 2013/7A/97.

\section{Postanowienia T K}

Postanowienie TK z 19 grudnia 2001 r., sygn. akt SK 8/01, OTK ZU 2001/8/272.

Postanowienie TK z 24 października 2001 r., sygn. akt SK 10/01, OTK ZU 2001/7/225.

Postanowienie pełnego składu TK z 23 stycznia 2002 r., sygn. akt Ts 105/00, OTK ZU 2002/1B/60.

Postanowienie TK z 26 czerwca 2002 r., sygn. akt SK 1/02, OTK ZU 2002/4A/53.

Postanowienie TK z 1 października 2003 r., sygn. akt SK 29/02, OTK ZU 2003/8A/87.

Postanowienie TK z 14 grudnia 2004 r., sygn. akt SK 26/02, OTK ZU 2004/11A/120.

Postanowienia TK z 8 listopada 2005 r., sygn. akt: Ts 203/04, OTK ZU 2005/6B/237.

Postanowienie TK z 8 listopada 2005 r., sygn. akt Ts 204/04, OTK ZU 2005/6B/239.

Postanowienie TK z 21 marca 2006 r., sygn. akt Ts 49/06 OTK ZU 2006/5B/237.

Postanowienie TK z 4 września 2007 r., sygn. SK 47/06, OTK ZU 2007/8A/99.

Postanowienie TK z 10 października 2007 r., sygn. akt Ts 91/07, OTK ZU 2007/5B/254.

Postanowienie TK z 20 grudnia 2007 r., sygn. akt SK 67/05, OTK ZU 2007/11A/168.

Postanowienie TK z 8 kwietnia 2008 r., sygn. akt SK 80/06, OTK ZU 2008/3A/51.

Postanowienia pełnego składu TK z 16 lutego 2009 r., sygn. akt Ts 202/06, OTK ZU nr 2009/1B/23.

Postanowienie TK z 2 grudnia 2010 r., sygn. akt SK 11/10, OTK ZU 2010/10A/131.

Postanowienie TK z 21 grudnia 2010 r., sygn. akt Ts 16/10, OTK ZU 2014/2B/798.

Postanowienie TK z 6 kwietnia 2011 r., sygn. akt SK 21/07, OTK ZU 2011/3A/28.

Postanowienie TK z 13 czerwca 2011 r., sygn. akt SK 26/09, OTK ZU 2011/5A/46.

Postanowienie TK z 18 grudnia 2013 r., sygn. akt Ts 13/12, OTK ZU 2014/IIB/833.

Postanowienie TK z 4 kwietnia 2014 r., sygn. akt Ts 309/13,OTK ZU 2014/2B/176.

Postanowienie TK z 30 kwietnia 2014 r., sygn. akt Ts 73/14, OTK ZU 2014/4B/362.

Postanowienie TK z 16 czerwca 2014 r. sygn. akt Ts 214/13, OTK ZU 2015/5B/435.

Postanowienie TK z 3 lipca 2014 r., sygn. akt Ts 43/14, OTK ZU 2014/4B/357.

Postanowienie TK z 11 lipca 2014 r., sygn. akt Ts 22/14, OTK ZU 2014/4B/353.

Postanowienie TK z 23 października 2014 r., sygn. akt Ts 81/13, OTK ZU 2014/5B/ 417.

Postanowienie TK z 18 lutego 2015 r., sygn. akt P 48/13, OTK ZU 2015/2A/22.

Postanowienie TK z 18 lutego 2015 r., sygn. akt S 2/15, OTK ZU 2015/2A/23.

Orzeczenia innych sądów

Uchwała SN z 19 grudnia 2008 r., sygn. akt III CZP 122/08.

Postanowienie SN z 12 stycznia 2011 r., sygn. akt CSK 182/10.

Wyrok SN z 13 kwietnia 2012 r., sygn. akt I CSK 451/11.

Postanowienie NSA z 6 sierpnia 2014 r., sygn. akt II FSK 115/14.

Wyrok SN z 24 listopada 2015 r., sygn. akt II CSK 517/14.

Wyrok SN z 17 marca 2016 r., sygn. akt V CSK 337/15. 
Wyrok NSA z 12 kwietnia 2016 r., sygn. akt II FSK 330/15.

Wyrok SN z 15 września 2017 r., sygn. akt III CSK 241/16.

Postanowienie SN Izba Karna z 14 czerwca 2018 r., sygn. akt II KZ 19/18.

PIŚMIENNICTWO

Banaszak B., Jakie zmiany w Konstytucji RP sa potrzebne, [w:] Aktualne problemy reform konstytucyjnych, red. S. Bożyk, Temida 2, Białystok 2013.

Banaszak B., Opinia o zgodności z Konstytucja RP przedłożonego przez Prezydenta projektu ustawy o Sązie Najwyższym, druk nr 2003, VIII kadencja Sejmu. Opinie Biura Analiz Sejmowych, <http://www.sejm.gov.pl>.

Czeszejko-Sochacki Z., Formy naruszenia konstytucyjnych wolności lub praw, [w:] Skarga konstytucyjna, red. J. Trzciński, Wydawnictwo Sejmowe, Warszawa 2003.

Daniluk D., Skutki wyroku Trybunału Konstytucyjnego z klauzula odraczająca w postępowaniu sądowoadministracyjnym, „Przegląd Prawa Konstytucyjnego” 2011, nr 4.

Dobrowolski M., Opinia o zgodności z Konstytucją RP przedlożonego przez Prezydenta projektu ustawy o Sądzie Najwyższym, druk nr 2003, VIII kadencja Sejmu. Opinie Biura Analiz Sejmowych, <http://www.sejm.gov.pl>.

Domańska A., Zasady sprawiedliwości społecznej we współczesnym polskim prawie konstytucyjnym, Wydawnictwo Uniwersytetu Łódzkiego, Łódź 2001.

Dudek D., Konstytucyjna wolność człowieka a tymczasowe aresztowanie, Lubelskie Wydawnictwa Prawnicze, Lublin 2000,

Florczak-Wątor M., Skarga konstytucyjna jako środek ochrony konwencyjnych praw $i$ wolności jednostki, [w:] Prawo międzynarodowe i europejskie a sadownictwo konstytucyjne, red. P. Tuleja, Wydawnictwo Jak, Kraków 2015.

Garlicki L., Sąy a Konstytucja Rzeczypospolitej Polskiej, „Przegląd Sądowy” 2016, nr 7-8.

Gutowski M., Kardas P., Sąowa kontrola konstytucyjności prawa. Kilka uwag o kompetencjach sądów powszechnych do bezpośredniego stosowania konstytucji, „Palestra” 2016, nr 4.

Jarosz-Żukowska S., Prawo do skargi konstytucyjnej - stan obecny i postulaty de lege ferenda, [w:] Realizacja i ochrona konstytucyjnych wolności i praw jednostki w polskim porzadku prawnym, red. M. Jabłoński, Wydawnictwo Uniwersytetu Wrocławskiego, Wrocław 2014 r.

Jarosz-Żukowska S., W sprawie pożądanych zmian polskiego modelu skargi konstytucyjnej, [w:] Konieczne i pożądane zmiany Konstytucji RP z 2 kwietnia 1997 r., red. B. Banaszak, M. Jabłoński, Wydawnictwo Uniwersytetu Wrocławskiego, Wrocław 2010.

Liszcz T., Głos w dyskusji, [w:] Księga XXV-lecia Trybunału Konstytucyjnego. Ewolucja funkcji i zadań Trybunału Konstytucyjnego — założenia a ich praktyczna realizacja, red. K. Budziło, Biuro Trybunału Konstytucyjnego, Warszawa 2010.

Łabno A., Skarga konstytucyjna jako środek ochrony praw człowieka. Przyczynek do dyskusji, „Przegląd Prawa Konstytucyjnego” 2012, nr 4.

Matczak M., Opinia prawna w sprawie konstytucyjności prezydenckiego projektu ustawy o Sadzie Najwyższym, druk nr 2003, VIII kadencja Sejmu. Opinie Biura Analiz Sejmowych, $<\mathrm{http}: / /$ www.sejm.gov.pl $>$.

Masternak-Kubiak M., Zakolska J., Naruszenie zasady proporcjonalności jako podstawa skargi konstytucyjnej, [w:] W stużbie dobru wspólnemu. Księga dedykowana Profesorowi Januszowi Trzcińskiemu, red. M. Masternak-Kubiak, R. Balicki, Wydawnictwo Sejmowe, Warszawa 2012, s. 234-237.

Patyra S., Opinia prawna na temat zgodności z Konstytucją Rzeczypospolitej Polskiej przedstawionego przez Prezydenta Rzeczpospolitej Polskiej projektu ustawy o Sadzie Najwyższym, druk nr 2003, VIII kadencja Sejmu. Opinie Biura Analiz Sejmowych, <http://www.sejm.gov.pl>. 
Radziewicz P., ,Przywilej korzyści” jako skutek prawny orzeczenia Trybunału Konstytucyjnego, „Przegląd Legislacyjny” 2006, nr 4.

M. Safjan, Pozycja Trybunału Konstytucyjnego w Konstytucji Rzeczypospolitej Polskiej z 1997 roku. Nowe instrumenty i metody działania, [w:] Pięć lat Konstytucji Rzeczypospolitej Polskiej, red. H. Jerzmański, Warszawa 2002.

Tuleja P., Skarga konstytucyjna w Polsce — dziesięć lat doświadczeń, „Przegląd Legislacyjny” 2007, nr 3(61).

Tuleja P., Stosowanie Konstytucji RP w świetle zasady jej nadrzędności, Wolters Kluwer, Kraków 2003.

Tuleja P., Wróbel W., Skarga konstytucyjna, czyli dodatkowa gwarancja praw człowieka. W Polsce i gdzie indziej, „Rzeczpospolita” nr 265, 14 XII 1997.

Wiącek M., Formalne przesłanki skargi konstytucyjnej (w świetle orzecznictwa TK), „Państwo i Prawo" 2011, z. 9. 